Article

\title{
Evaluation of the Two-Stage Fermentative Hydrogen Production from Sugar Beet Molasses
}

\author{
Robert Grabarczyk ${ }^{\oplus}$, Krzysztof Urbaniec ${ }^{\circledR}$, Jacek Wernik*(D) and Marian Trafczynski $₫$ \\ Faculty of Civil Engineering, Mechanics and Petrochemistry, Warsaw University of Technology, Łukasiewicza 17, \\ 09-400 Płock, Poland; robert.grabarczyk@pw.edu.pl (R.G.); krzysztof.urbaniec@pw.edu.pl (K.U.); \\ marian.trafczynski@pw.edu.pl (M.T.) \\ * Correspondence: jacek.wernik@pw.edu.pl; Tel.: +48-24-367-22-12
}

Received: 28 August 2019; Accepted: 25 October 2019; Published: 26 October 2019

check for updates

\begin{abstract}
Fermentative hydrogen production from molasses-a renewable by-product of beet-sugar processing - was considered. Technical and economic evaluations were performed of a stand-alone production plant employing a two-step fermentation process (dark thermophilic fermentation and photofermentation) followed by an adsorption-based upgrading of the produced hydrogen gas. Using a state-of-the-art knowledge base and a mathematical model composed of mass and energy balances, as well as economic relationships, the process was simulated and equipment data were estimated, the hydrogen cost was calculated and a sensibility analysis was carried out. Due to high capital, operating and labor costs, hydrogen production cost was estimated at a rather high level of $32.68 \mathrm{EUR} / \mathrm{kg}$, while the energy output in produced hydrogen was determined as $68 \%$ more than the combined input of the thermal and electric energy needed for plant operation. As the room for improvement of plant performance is limited, a perspective on the cost competitiveness of large-scale hydrogen production from fossil sources is unclear.
\end{abstract}

Keywords: biohydrogen; thermophilic fermentation; photofermentation; beet molasses; techno-economic analysis

\section{Introduction}

On a global scale at present, fossil fuels constitute the main energy source [1,2]. In view of the increasing energy demand, growing greenhouse-gas emissions that contribute to climate changes and dwindling fuel reserves, new and cleaner energy technologies need to be developed $[3,4]$. The use of hydrogen as a clean energy carrier has been considered as an alternative to fossil-fuel-based energy supply that is inevitably accompanied by carbon dioxide emissions [5]. However, growing interest in hydrogen fuel is in contrast to the fact that, at present, most of the hydrogen produced worldwide comes from thermo-chemical processing of fossil fuels and, therefore, is concurrent with the liberation of carbon compounds [6]. As real benefits for carbon dioxide abatement can only be obtained if hydrogen is produced from renewable resources, a search is under way for sustainable and environmentally friendly hydrogen production routes and supply chains, such as processing of biomass or by-products derived from biomass-based industries [7,8]. One of the most interesting concepts of hydrogen production from biomass is the two-step fermentative process-dark fermentation followed by photofermentation - which has the advantage of moderate values of process parameters including pressure and temperature [9,10]. Molasses, a renewable by-product of sugar manufacturing from sugar beet or sugar cane, was identified as a suitable feedstock for hydrogen fermentation already a decade ago [11]. This was followed by an evaluation of its suitability for industrial application, however using a simplified economic model and cost data from the period before 2013 [12]. Research on fermentative hydrogen production from molasses was later continued dealing separately with dark 
fermentation [13,14] and photofermentation [15]. Economic analysis of hydrogen production from molasses by mesophilic dark fermentation was performed assuming a rather small energy output of 0.008-0.04 MW [16].

In view of Poland's energy supply strategy, including the trend towards increased share of clean and renewable energy in accordance with the requirements imposed by the European Union [17], some major Polish companies are active in the development of hydrogen technologies and creation of hydrogen infrastructure. Oil refining companies Orlen and Lotos, fertilizer producer Grupa Azoty, as well as the coal mining and processing company Jastrzębska Spółka Wẹglowa S.A., all intend to sell surplus hydrogen generated in their production processes, while both Orlen and the power company PGE are planning hydrogen production by electrolysis using electricity from wind power farms [18]. In this context, other renewable energy sources like by-products derived from biomass-based industries-including molasses-also deserve consideration. This is in line with the sugar manufacturers' interest in extending the range of application of their primary by-products [19].

Poland is Europe's third largest, after France and Germany, producer of sugar from sugar beet. In Polish sugar factories, the yield of molasses (at $47 \%$ sucrose content) is around 3.5\% of the mass of beet processed [20]. At the total molasses output, which in the 2018/2019 beet campaign amounted to approx. $500,000 \mathrm{t}$, the theoretical potential of two-step fermentative hydrogen production from molasses is $32,900 \mathrm{t}$ annually [21]. Recognizing that, the present authors aim to evaluate the application potential of the said technology in Poland under the current economic conditions. Using a state-of-the-art knowledge base and a mathematical model composed of mass and energy balances, as well as economic relationships, the process is simulated and equipment data are estimated, hydrogen cost is calculated and a sensibility analysis is carried out. In the economic analysis, a discounted cash-flow method is employed and the scheme of governmental support for investments in renewable energy [22] is taken into account. On the basis of the calculation results, main directions of process and plant improvements, and a perspective on the cost competitiveness of large-scale hydrogen production from fossil sources, are discussed.

\section{Materials and Methods}

\subsection{Description of the Process}

The two-step process concept considered in this paper is based on the results of research project HYVOLUTION [9]. Contributions from follow-up studies are also taken into account $[12,23,24]$. The design studies performed as part of the HYVOLUTION work programme included analyses of two plant concepts: A stand-alone plant relying on feedstock supply from outside [25] and an add-on plant energy-integrated with the feedstock source exemplified by a beet-sugar factory [26]. The former concept is adopted in the present study.

A block diagram of the stand-alone plant employing the said concept for hydrogen production from molasses is shown in Figure 1. In order to maximize hydrogen yield, dark fermentation is assumed to employ microorganisms whose optimal temperature range is above $60^{\circ} \mathrm{C}$ and, therefore, the first process stage is called thermophilic fermentation [27].

The hypothetical plant is composed of three main units: Thermophilic fermentation (THF), photofermentation (PHF) and gas upgrading (GU). Additionally, the plant includes two units not shown in Figure 1: A low-pressure steam boiler and a cooling tower that are needed for providing heating steam and cooling water to the two-stage process. The process heat demand is reduced by thermal integration of the two fermentation stages [28]. The effluent from the thermophilic fermentation flows through a plate heat exchanger where it heats up the external recycling stream or make-up water supplied for molasses dilution. 


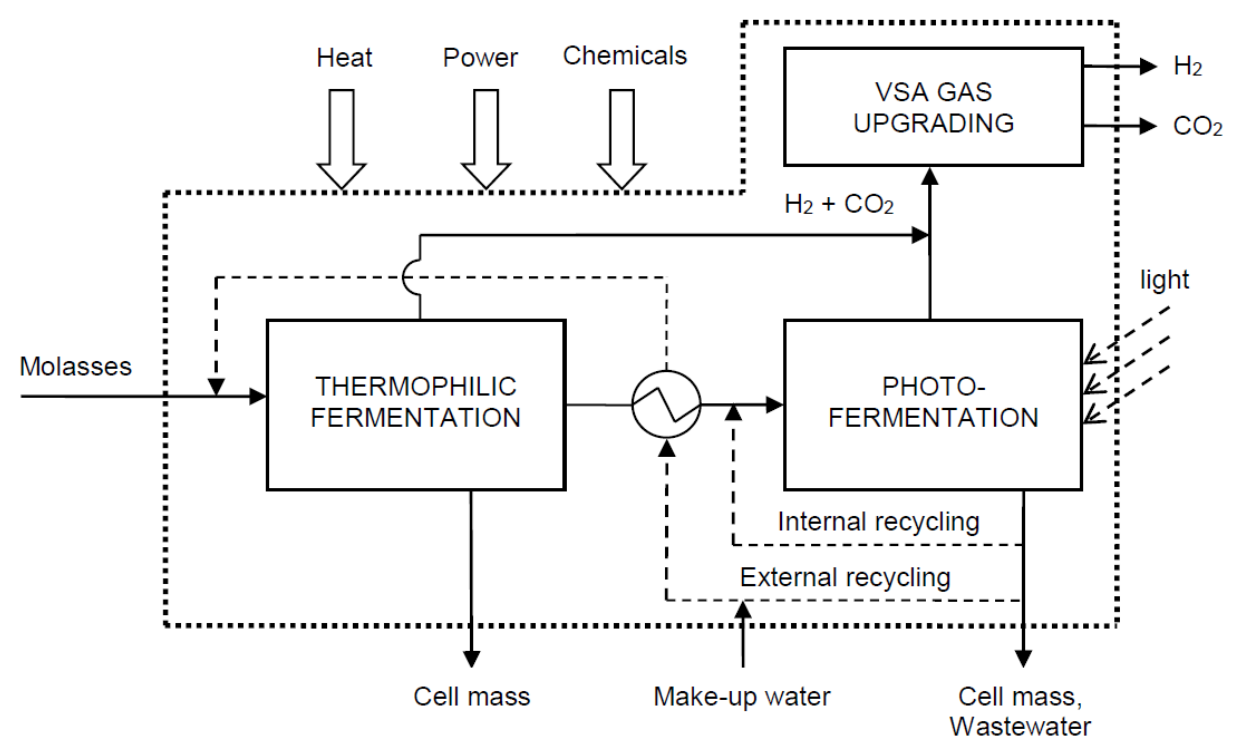

Figure 1. Scheme of hydrogen production from molasses using two-step fermentation. VSA: vacuum-swing adsorption.

The optimum $\mathrm{pH}$ values of the fermentation broths in thermophilic fermentation and photofermentation are 6.5 and 7.3, respectively. The stabilization of $\mathrm{pH}$ necessitates the use of chemicals like potassium hydroxide $(\mathrm{KOH})$ and phosphates.

The scheme of the thermophilic fermentation unit is shown in Figure 2.

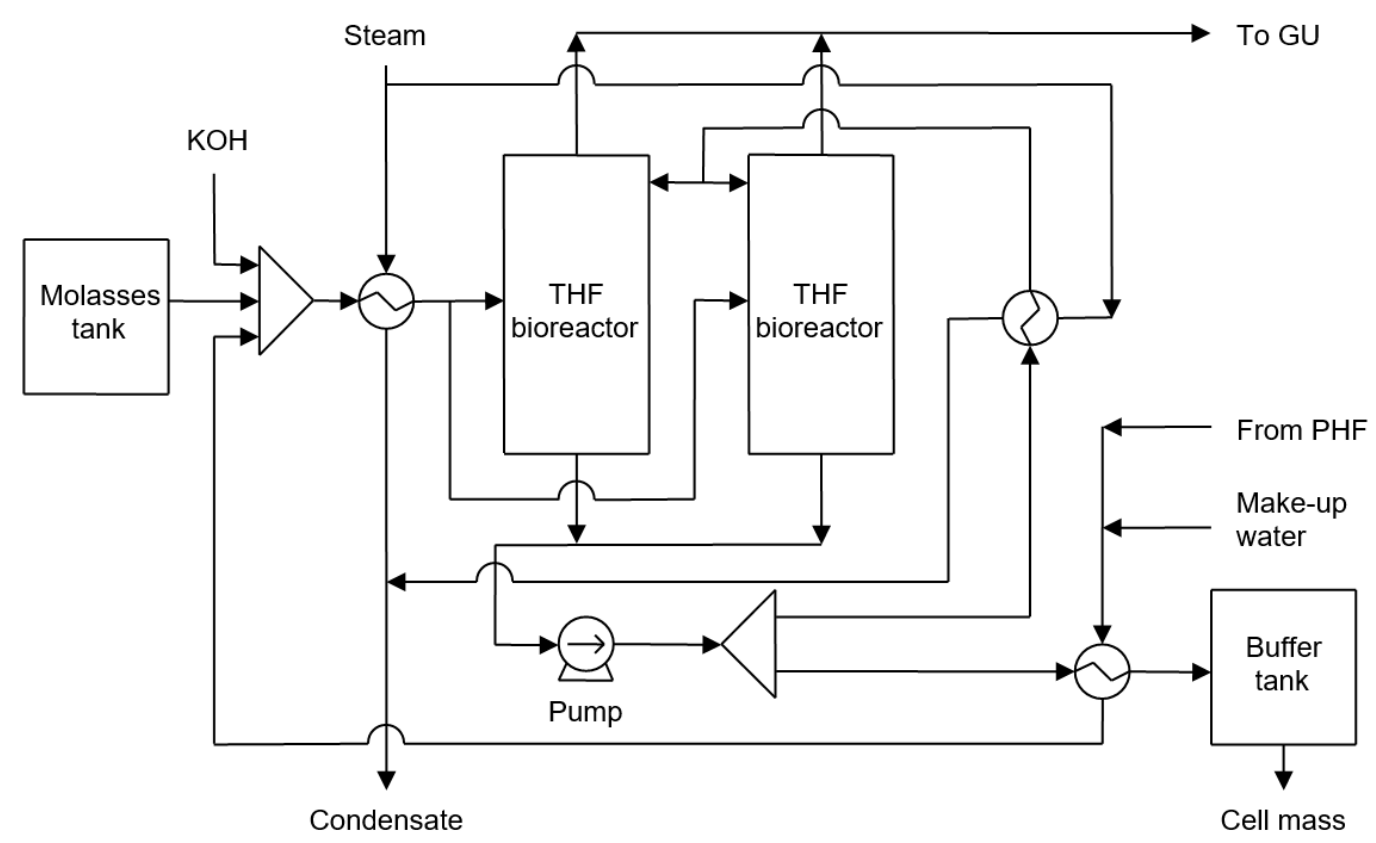

Figure 2. Scheme of the thermophilic fermentation unit.

The molasses, which comes from a long-term storage tank at $10^{\circ} \mathrm{C}$, is mixed with water so as to reach appropriate substrate concentration, then heated up in a plate heat exchanger and supplied to two thermophilic bioreactors working in parallel where sucrose conversion to hydrogen, carbon dioxide and acetic acid takes place. To achieve a high $\mathrm{H}_{2}$ yield, a temperature of about $70{ }^{\circ} \mathrm{C}$ and pressure below $50 \mathrm{kPa}$ are maintained in the bioreactor whose heat demand is covered by steam heating of the recycled fermentation broth in a plate heat exchanger. 
Spent fermentation broth containing acetic acid is discharged from the bioreactor, cooled down in another plate heat exchanger and directed to a buffer tank. The tank has two functions: Sedimentation of the bacterial biomass and temporary broth storage during a nighttime period of inactivity of photofermentation. Upon photofermentation restart, the broth is diluted into the required concentration of acetic acid and pumped to the photofermentation unit, which is schematically shown in Figure 3.

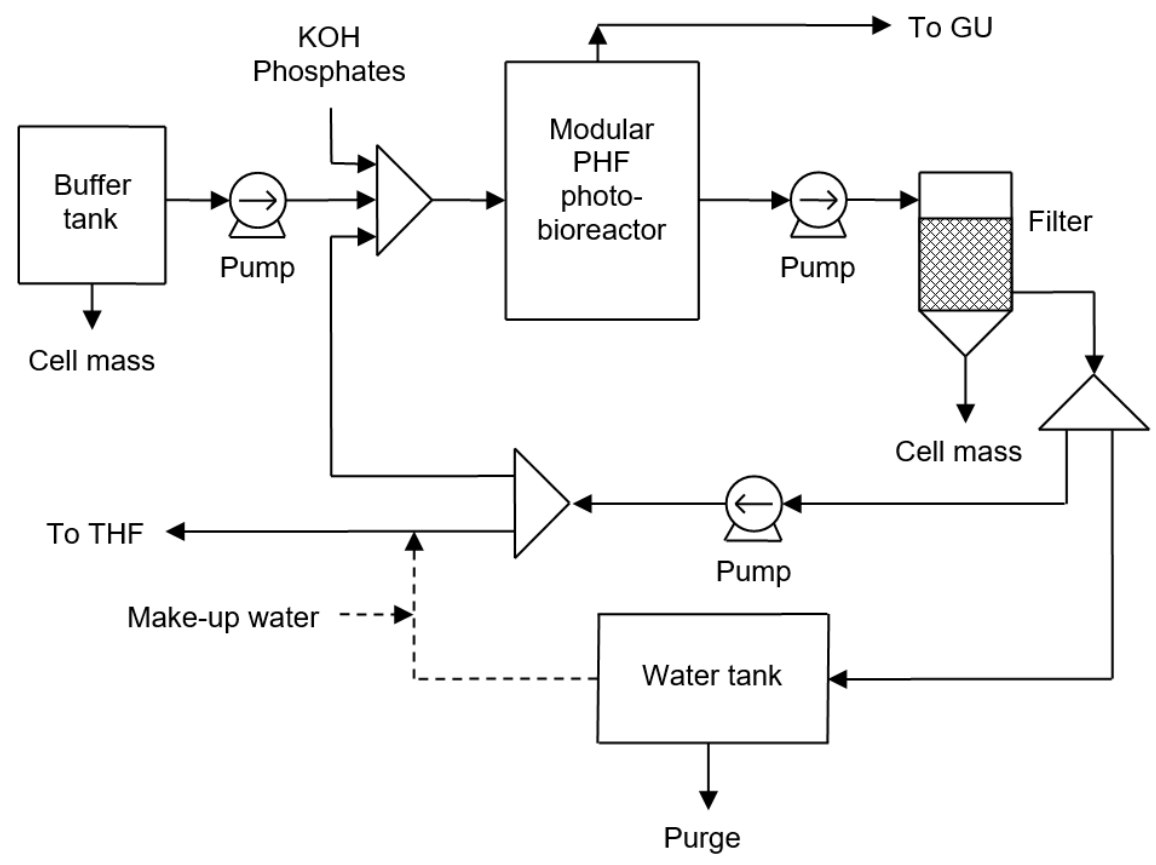

Figure 3. Scheme of the photofermentation unit.

In the photobioreactor where a temperature of $30^{\circ} \mathrm{C}$ and atmospheric pressure are maintained, and photo-heterotrophic bacteria are exposed to sunlight, acetic acid is reduced to $\mathrm{H}_{2}$ and $\mathrm{CO}_{2}$. Spent photofermentation broth, after treatment in candle filters where bacterial biomass is separated, is converted to effluent (water containing small amounts of sucrose and acetic acid) that can be recycled to the fermentation stages. Surplus effluent, stored in a water tank, is available for the dilution of molasses during the period of photofermentation inactivity. Molasses can also be diluted using make-up water if needed.

It is assumed that hydrogen production plant is equipped with three units for the preparation of fermentation bacteria: two units to serve the two thermophilic bioreactors and another unit to serve the photobioreactor. Each unit includes three vessels for bacteria growth (estimated volumes $0.1,1$ and $10 \mathrm{~m}^{3}$ ), two regular pumps and a dosing pump.

Contrary to most of previous studies in which gas upgrading by amine-absorption was assumed $[25,26]$, the present work adopts the concept of hydrogen purification by vacuum-swing adsorption (VSA) [12,29]. A gaseous mixture produced in the bioreactors flows to the adsorption unit where $\mathrm{CO}_{2}$ is separated on a molecular sieve $13 \mathrm{X}$ (lifetime $40,000 \mathrm{~h}$ ). The scheme of the gas upgrading unit employing VSA is shown in Figure 4. It includes three adsorption-desorption vessels operated in batch mode, with their operation cycles coordinated so as to ensure near-continuous operation of the entire gas upgrading unit. The molar ratio of hydrogen to carbon dioxide in the gas mixture produced in the bioreactors is 2:1, which corresponds to the mass fractions in the dry gas 0.083 and 0.917 of $\mathrm{H}_{2}$ and $\mathrm{CO}_{2}$, respectively. While VSA is less energy-intensive than amine absorption, an inherent problem of VSA application is that separation efficiency of the adsorption-desorption cycle is limited. It is assumed that $10 \%$ of the produced hydrogen is lost with the outflowing $\mathrm{CO}_{2}$ stream, while the molar composition of the produced stream of hydrogen gas is 3\% carbon dioxide and $97 \%$ hydrogen. This level of hydrogen purity may be acceptable for hydrogen use in high-temperature solid oxide fuel cells. 
As an alternative - not considered in the present study—the produced hydrogen could be supplied to an external amine-absorption facility for processing to a higher purity.

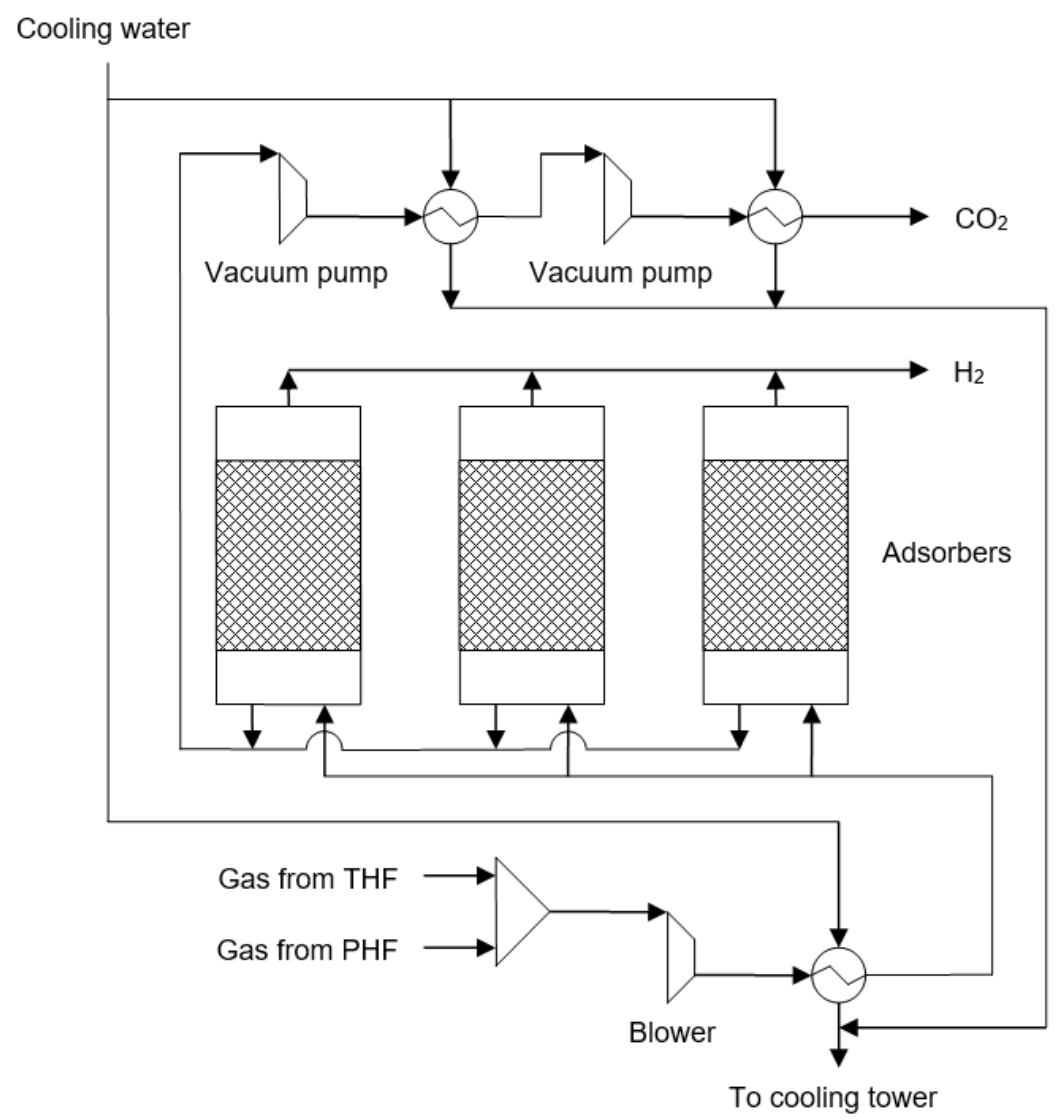

Figure 4. Scheme of the gas upgrading unit.

\subsection{Process Modelling}

The stoichiometric reactions of the thermophilic fermentation and the photofermentation are expressed by Equations (1) and (2), respectively:

$$
\begin{gathered}
\mathrm{C}_{12} \mathrm{H}_{22} \mathrm{O}_{11}+5 \mathrm{H}_{2} \mathrm{O} \rightarrow 4 \mathrm{CH}_{3} \mathrm{COOH}+8 \mathrm{H}_{2}+4 \mathrm{CO}_{2}, \\
\mathrm{CH}_{3} \mathrm{COOH}+2 \mathrm{H}_{2} \mathrm{O} \rightarrow 4 \mathrm{H}_{2}+2 \mathrm{CO}_{2} .
\end{gathered}
$$

In the thermophilic fermentation the theoretical yield of hydrogen is eight moles per one mole of sucrose whereas in photofermentation, the theoretical yield of hydrogen is $4 \mathrm{~mol} / \mathrm{mol}$ of acetic acid. In the real bioprocesses, however, the theoretical yields cannot be achieved because the substrates are partly consumed by fermentative bacteria. According to experimental results published by research teams that worked on dark fermentation as well as on photofermentation, approximately $15 \%$ of the substrates is converted to biomass cells [11,30].

The mass balance of the hydrogen plant can be determined on the basis of elementary balance equations of the two-stage process. In order to carry out the present study, the mathematical model of the plant including mass and energy balance equations was developed and implemented in Microsoft Excel. This made it possible to determine the plant's energy yield defined as the ratio of the energy flow in produced hydrogen to the sum of the average heat and power demands of the plant. The mathematical model incorporates economic relationships. To assess the two-stage process from the economic point-of-view, net present value (NPV) was used [31]. The hydrogen production cost was assumed equal to the minimum price of hydrogen at which NPV $=0$ at 15 years operation time and a 
one-year building time of the plant. Furthermore, a $6 \%$ discount rate, investment credit with a $2 \%$ interest rate and a 10-year repayment period were assumed.

The capital cost was calculated on the basis of the purchase prices of the necessary land and process equipment. These two prices are interrelated because photobioreactor design determines the required land area thus affecting its purchase price. Major equipment pieces were sized, and their purchase prices were estimated on the basis of simulation results, including mass and energy balances of the production process. The purchase prices of pressure vessels, thermophilic bioreactors, pumps, compressors, air cooler and shell-and-tube heat exchangers, were calculated using Equation (3) [32]:

$$
\mathrm{C}_{\mathrm{eq}}=\mathrm{C}_{\mathrm{B}}\left(\mathrm{Q} / \mathrm{Q}_{\mathrm{B}}\right)^{\mathrm{M}}
$$

where $C_{\text {eq }}$ denotes the purchase price of the equipment piece with capacity $Q, C_{B}$ is the known base purchase price of the equipment piece with capacity $\mathrm{Q}_{\mathrm{B}}$, and $\mathrm{M}$ is the constant characteristic of the equipment type considered.

A different approach was adopted for the estimation of purchase prices of plate heat exchangers. For the exchanger with heat transfer area $\mathrm{A}$, the price is

$$
\mathrm{C}_{\mathrm{PHE}}=\mathrm{A} \cdot \mathrm{D}+\mathrm{E}
$$

where $\mathrm{D}$ and $\mathrm{E}$ are constants characteristic of the type of plate heat exchanger.

In order to perform calculations using Equations (3) and (4), the values of base purchase prices $C_{B}$ and constants $D$ and $E$ were assumed on the basis of costing data obtained from a friendly Polish engineering company, whereas the values of constant $M$ for various equipment types were adopted after Smith and Sinnott [33,34].

A design study was carried out to estimate the purchase price of the photobioreactor formed as an array of tubular modules in which broth flow and hydrogen separation take place. A single module was assumed to consist of two headers connected with a bank of transparent $50 \mathrm{~m}$-long LDPE tubes whose combined illuminated area is $380 \mathrm{~m}^{2}$ and working volume is $14.6 \mathrm{~m}^{3}$, a broth pump and piping for broth inlet/outlet and hydrogen discharge. The photobioreactor module is schematically shown in Figure 5.

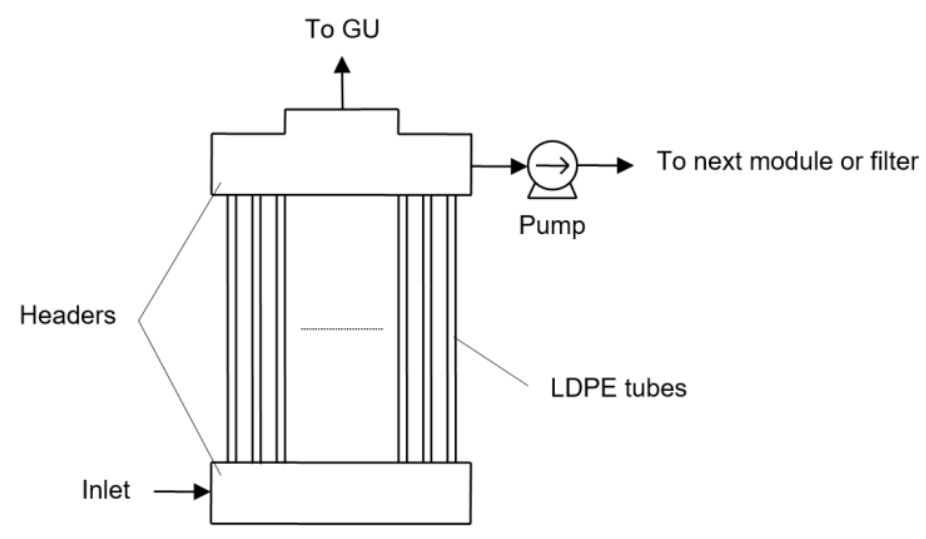

Figure 5. Scheme of the single photobioreactor module.

LDPE tubes are placed on the ground in a slightly inclined position to facilitate hydrogen separation from the broth in the upper header. The tubes used the photobioreactor have a short lifetime and require replacement once a year. The estimated purchase price of one module was 5500 EUR, while the number of modules was determined after estimating the photobioreactor size. 
The total capital investment is equal to the total purchase price of all equipment pieces $\Sigma \mathrm{C}_{\text {eq }}$ multiplied by the Lang factor $\mathrm{F}_{\mathrm{L}}$ plus land price $\mathrm{C}_{\mathrm{L}}$ :

$$
\mathrm{TCI}=\Sigma \mathrm{C}_{\mathrm{eq}} \cdot \mathrm{F}_{\mathrm{L}}+\mathrm{C}_{\mathrm{L}}
$$

In analogy with other types of process equipment [33], it was assumed that for thermophilic fermentation, gas upgrading, steam boilers and water-cooling units the Lang factor is 3 whereas for the photofermentation unit the Lang factor is 2.

The operating cost was calculated as a sum of the costs of maintenance, chemicals, molecular sieve, heating steam, electricity and cooling water needed to keep the production process running. The annual maintenance cost of the plant was assumed equal to the cost of annual replacement of LDPE tubes in the photofermentation unit, plus 5\% the total capital cost. To calculate labor cost, it was assumed that three skilled workers are needed for operating the hydrogen plant, while for the replacement of LDPE tubes in one photobioreactor module, 24 man-hours of unskilled workers are required. The costs of raw material (molasses), chemicals, steam, power and cooling water were estimated using the results of process simulation and prices, or specific costs as shown in Table 1.

Table 1. Costing data used in the economic analysis [35-37].

\begin{tabular}{ccc}
\hline Price or Specific Cost & Value & Unit \\
\hline Molasses & 126 & EUR/t \\
Electric energy & 0.13 & EUR/kWh \\
Steam, 200 kPa & 24.2 & EUR/t \\
Cooling water & 0.017 & EUR/t \\
Potassium hydroxide & 148 & EUR/t \\
Phosphates & 509 & EUR/t \\
Molecular sieve 13X & 3000 & EUR/t \\
LDPE tube & 1.16 & EUR/m \\
Labor skilled/unskilled & $13,760 / 6720$ & EUR/man-year \\
Land & 6270 & EUR/ha \\
\hline
\end{tabular}

While the dark (thermophilic) fermentation unit is continuously operated, $8000 \mathrm{~h}$ per year, nighttime interruption of the photofermentation is taken into account by assuming that it is operated on average $10 \mathrm{~h}$ per day. A molasses tank is assumed to contain a molasses amount sufficient to cover total annual consumption of this raw material. Power consumed by the production plant is supplied from the external grid. To ensure that the results of the present study can be compared with those of the HYVOLUTION project, plant size is assumed equal to that of the conceptual HYVOLUTION plant; that is, $60 \mathrm{~kg} \mathrm{H}_{2} / \mathrm{h}$ in the produced hydrogen gas. At the $120 \mathrm{MJ} / \mathrm{kg}$ heating value of hydrogen, this is equivalent to an energy stream of $2 \mathrm{MW}$. The assumed values of parameters of the two-step fermentation process are listed in Table 2.

Table 2. Experimental results of the two-stage hydrogen fermentation of molasses $[11,30]$.

\begin{tabular}{ccc}
\hline Process Parameter & Value & Unit \\
\hline Thermophilic fermentation & & $\mathrm{g} / \mathrm{L}$ \\
Sucrose concentration & 10 & $\mathrm{mmol} / \mathrm{L} / \mathrm{h}$ \\
Hydrogen productivity & 16.3 & $\%$ \\
Conversion factor of sucrose & 70 & $\mathrm{mmol} / \mathrm{L}$ \\
Photofermentation & & $\mathrm{mmol} / \mathrm{L} / \mathrm{h}$ \\
Acetic acid concentration & 40 & $\%$ \\
Hydrogen productivity & 0.5 & \\
Conversion factor of acetic acid & 45 & \\
\hline
\end{tabular}




\section{Results and Discussion}

\subsection{Process Performance and Plant Characteristics}

In order to evaluate the functioning of a hydrogen production plant, two indices were adopted. In addition to the cost of hydrogen production as the economic index, energy yield as the technological index was defined as the ratio of the energy stream in produced hydrogen (based on its heating value) to the sum of thermal power and electric power needed for plant operation. Though the latter index does not account for differences in the thermodynamic values of the different energy streams, it allows to quickly compare the energy value of plant output with the necessary energy input.

On the basis of parameter values specified in Section 2, the production process was simulated, and equipment specification was determined. The main results are summarized in Table 3. In the nominal plant output of $60 \mathrm{~kg} \mathrm{H}_{2} / \mathrm{h}$, the share of photofermentation, that is, the time-averaged hydrogen stream from that process step, is $95.7 \times 10 / 24=39.9 \mathrm{~kg} \mathrm{H}_{2} / \mathrm{h}$ (around $66 \%$ ).

Table 3. Hydrogen plant specification.

\begin{tabular}{ccc}
\hline Parameter & Value & Unit \\
\hline Molasses demand & 1545 & $\mathrm{~kg} / \mathrm{h}$ \\
Thermophilic fermentation (continuous operation) & & $\mathrm{h}$ \\
Hydraulic retention time & 10 & $\mathrm{~kg} / \mathrm{h}$ \\
Hydrogen stream & 26.1 & $\mathrm{~m}^{3}$ \\
Bioreactor volume & $2 \times 530$ & $\mathrm{~m}^{3} / \mathrm{h}$ \\
External recycling stream & 88.8 & \\
Hydraulic retention time & & $\mathrm{h}$ \\
Hydrogen stream & 144 & $\mathrm{~kg} / \mathrm{h}$ \\
Land area of photobioreactor & 95.7 & $\mathrm{ha}$ \\
Internal recycling stream & 250 & $\mathrm{~m}^{3} / \mathrm{h}$ \\
\hline
\end{tabular}

The capacity of the molasses tank was $9200 \mathrm{~m}^{3}$. When both process steps are in operation, the effluent from the second process step is collected in the water tank of $1050 \mathrm{~m}^{3}$. During the night, when photofermentation is inoperative, that liquid is used for the dilution of molasses, while first-step effluent (i.e., second-stage fermentation broth) is collected in the buffer tank of $1200 \mathrm{~m}^{3}$. The consumption of fresh water is $3.4 \mathrm{~m}^{3}$ per day.

The time-averaged demand for thermal power to be supplied in the heating steam is $824 \mathrm{~kW}$ and the demand for electric power to drive flow machinery is $369 \mathrm{~kW}$. Bearing in mind that the produced hydrogen is equivalent to the energy stream of $2000 \mathrm{~kW}$, the energy yield is 1.68.

The total cost of investment is $88.7 \times 10^{6} \mathrm{EUR}$, and Figure 6 illustrates the cumulative cash flow.

The investment receives preferential financing in accordance with the governmental support scheme for renewable energy that requires an owner's contribution of not lower than $25 \%$ of the total cost. Assuming plant construction time is one year, the first year's cash flow is equal to the said contribution of $22.18 \times 10^{6}$ EUR. After that, NPV increases slowly during the ten-year period of credit repayment and faster afterwards, reaching zero after 15 years from plant start-up.

The hydrogen production cost is estimated at $32.68 \mathrm{EUR} / \mathrm{kg}$. Interestingly, this value is close to the estimated cost of hydrogen produced by a single-step process employing dark fermentation as mentioned in [16]. 


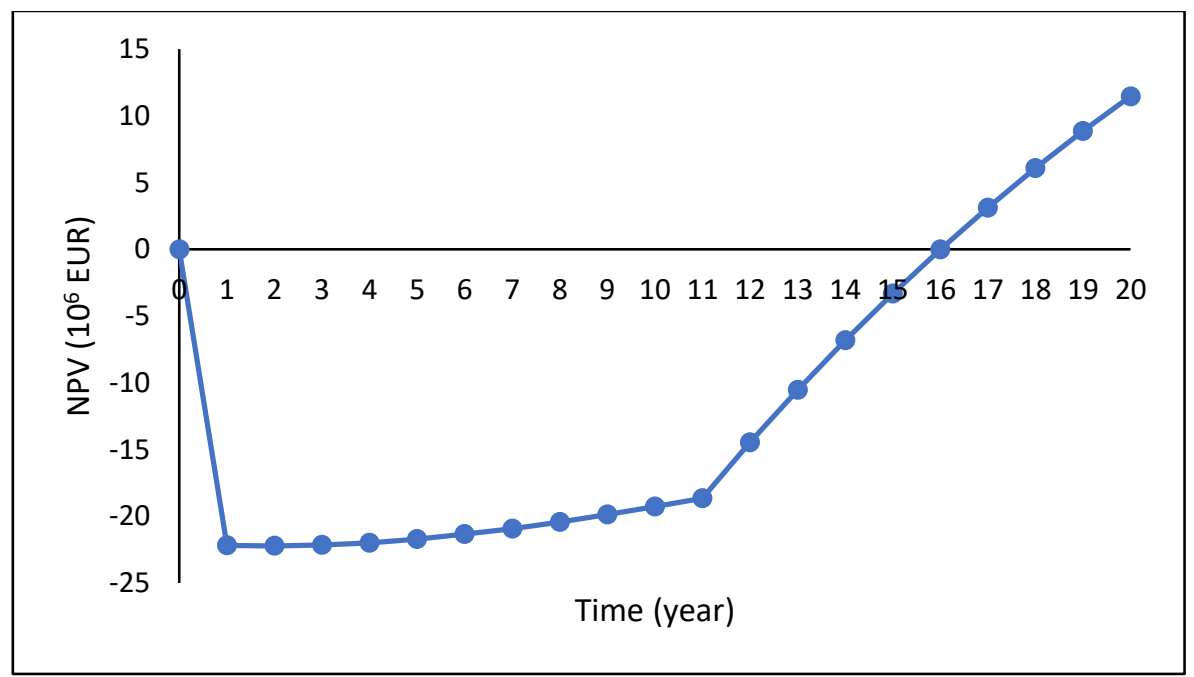

Figure 6. Cumulative cash flow diagram.

Figure 7a illustrates the structure of hydrogen production costs. Their main components are capital costs $(43 \%)$ and operating costs $(41 \%)$. As shown in Figure $7 \mathrm{~b}$, the largest share in capital costs $(87 \%)$ is attributed to the photofermentation unit. The capital costs also include less significant expenditures (below 1\%) on the steam boiler and on the cooling tower.

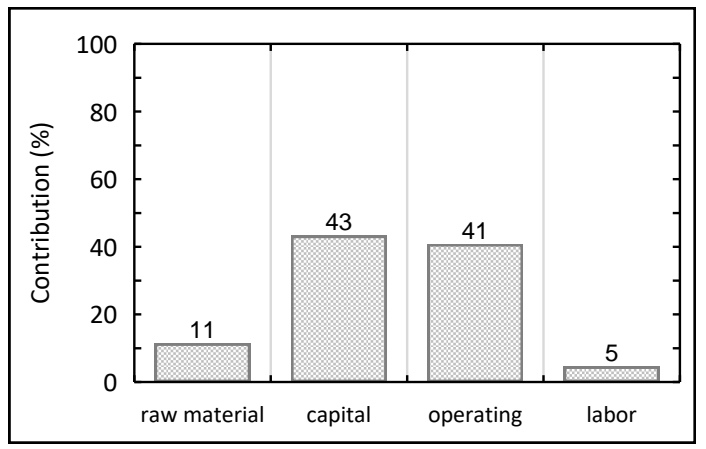

(a)

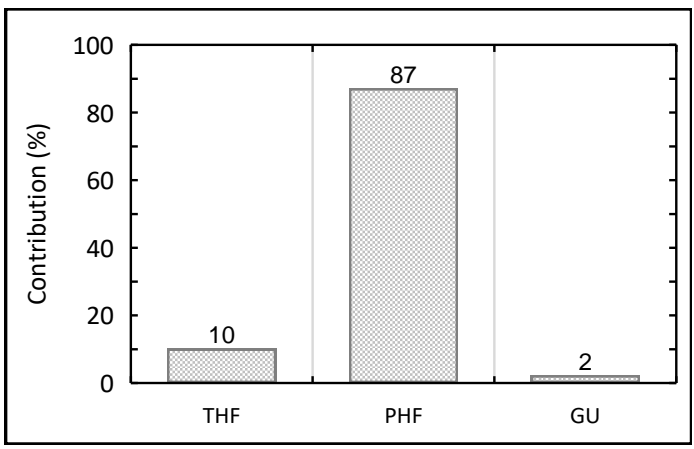

(b)

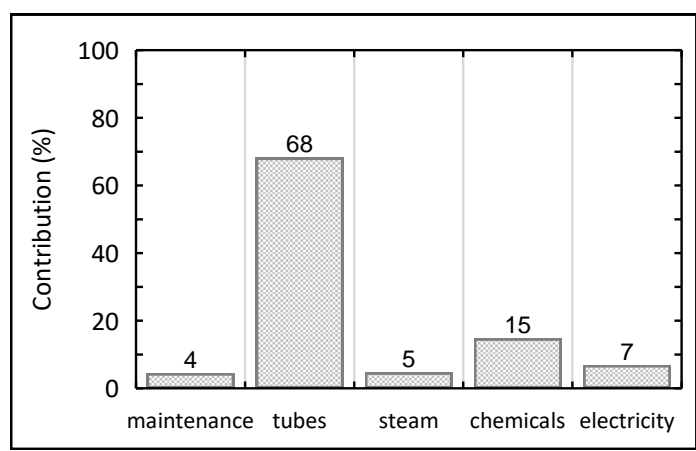

(c)

Figure 7. Cost structure: (a) Hydrogen production cost; (b) capital cost; and (c) operating cost. THF — thermophilic fermentation, PHF— photofermentation, and GU—gas upgrading.

Figure 7c illustrates the structure of operating costs of the hydrogen plant. Among the main plant components, the photofermentation unit has the largest share resulting from the cost of transparent tubes that need to be periodically replaced in photobioreactors of (annual cost $3.8 \times 10^{6}$ EUR). Labor costs amount to $0.63 \times 10^{6}$ EUR per year, of which the replacement of tubes generates the largest part 
(93\%). The operating costs also include less significant expenditures (below 1\%) on the cooling water supply and periodic replacement of molecular sieve 13X for the gas upgrading unit.

\subsection{Sensitivity Analyses}

As a complement to process simulation, equipment sizing and economic calculations, sensitivity analyses were performed. Their results can be regarded as a starting point for the estimation of possible process and plant improvements that may lead to the increase in energy yield and reduction of hydrogen cost. Regarding process parameters, sensitivity was investigated for energy yield and hydrogen production cost to changes, in the range $\pm 20 \%$, of the parameters listed in Table 2. Figure 8 depicts the relationships between energy yield change and changes in the values of four selected process parameters. Within the investigated range of parameter changes, the most significant improvement in the energy yield can be attributed to the increase in conversion factor of sucrose in thermophilic fermentation. Of the other process parameters whose effects on energy yield are indicated in Figure 8, both sucrose concentration in the solution supplied to thermophilic fermentation and hydrogen productivity in photofermentation are interesting because their values can probably be increased by more than $20 \%$ assumed in the sensitivity analysis (for the estimates of associated improvement of process performance, see the discussion of hydrogen cost sensitivity).

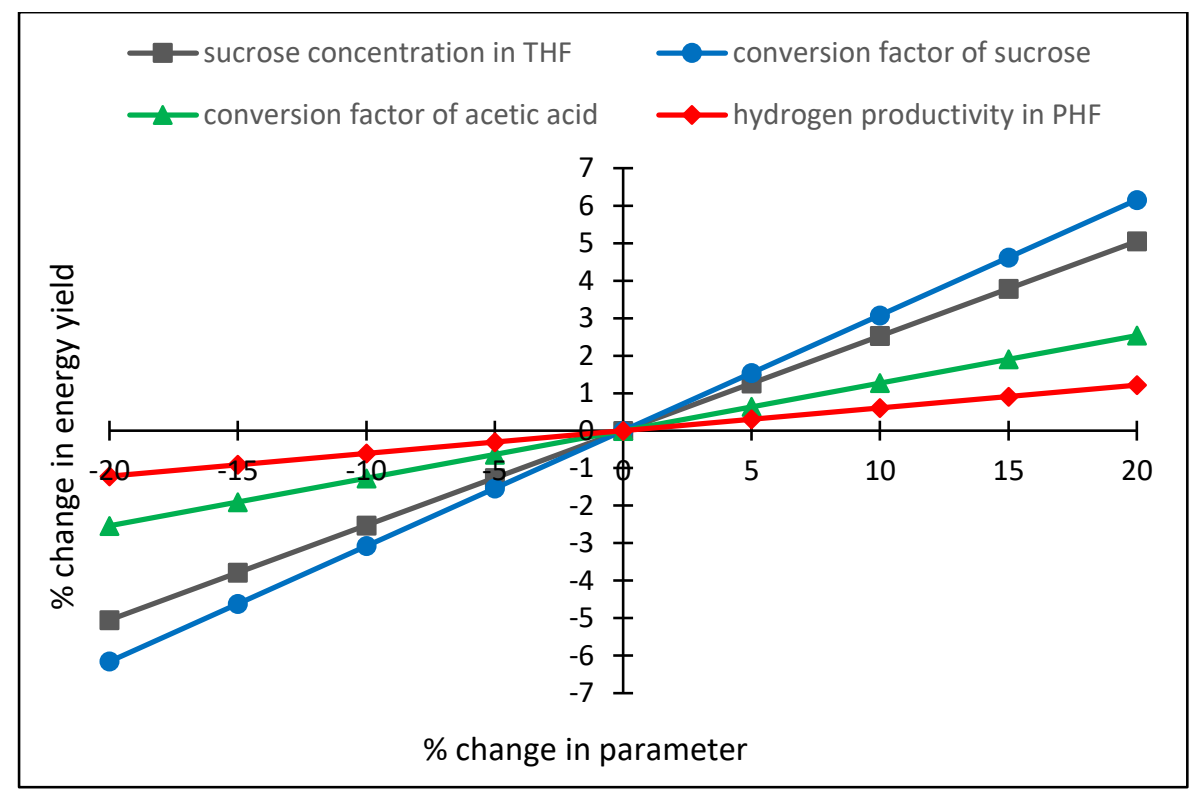

Figure 8. Energy yield sensitivity to process parameter change.

Figure 9 depicts the relationships between changes in hydrogen production cost and changes in the values of three selected process parameters (cost sensitivity to changes in other process parameters is negligible).

The most significant cost reduction can be attributed to the increase in hydrogen productivity in photofermentation. The effect on the costs is twofold: On the one hand, higher productivity reduces the required volume of the photofermentation unit as well as its footprint leading to lower capital cost; on the second hand, the total length of transparent tubes is reduced lowering the contribution of their periodic replacement to the operating cost. Further to the data shown in Figure 9, minor cost reductions could be obtained by increasing the conversion factor of sucrose in thermophilic fermentation, as well as by increasing the concentration of acetic acid in the solution supplied to photofermentation.

As some of the components of hydrogen costs are calculated using assumed prices shown in Table 1 and approximate Equations (3)-(5), there is an unavoidable uncertainty margin in the resulting cost values. For example, according to the literature [34], uncertainty in equipment costs may be 
around $\pm 25 \%$. In the present study, uncertainty of hydrogen production costs can be estimated by investigating its sensitivity to changes in the prices of selected items.

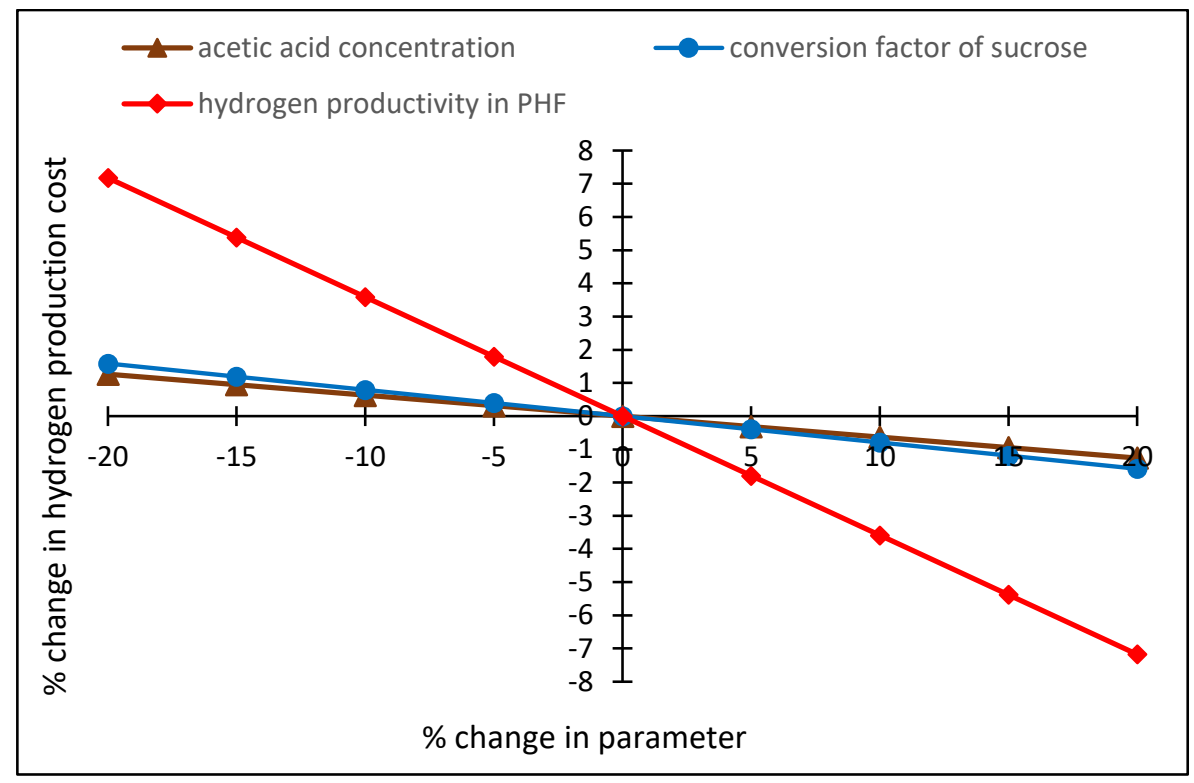

Figure 9. Hydrogen production cost sensitivity to process parameter change.

The investigation results shown in Figure 10 highlight the importance of the photofermentation unit to the determination of costs of two-stage hydrogen production. Changes in the range $\pm 25 \%$ of the purchase price of photobioreactor modules-directly influencing photobioreactor cost-lead to $\pm 10 \%$ changes of the costs. Uncertainty in the purchase price of transparent tubes-affecting operating costs-is less important because price changes in the range $\pm 25 \%$ result in $\pm 6 \%$ changes of hydrogen production costs. Sensitivity of the costs to molasses price is insignificant. It was also found that uncertainty associated with plant components other than the photofermentation unit is negligible (results not shown). Overall, the above estimates indicate that hydrogen costs are determined with an uncertainty margin wider than $\pm 10 \%$.

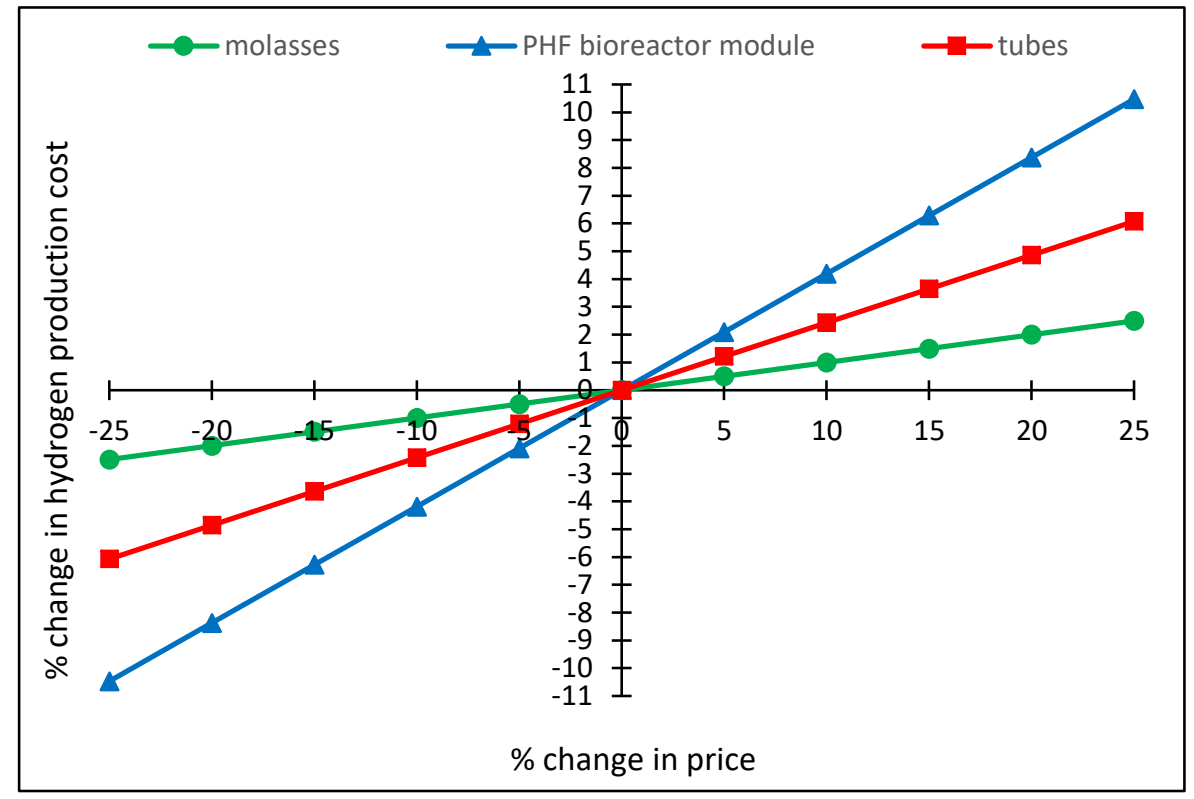

Figure 10. Hydrogen production cost sensitivity to selected prices. 


\subsection{Main Directions of Process and Plant Improvements}

In the energy demand mentioned in Section 3.1, around $97 \mathrm{~kW}$ of electric power is attributed to the operation of a VSA-based gas upgrading unit. If the amine absorption method of gas upgrading was applied instead, then in addition to an electric power demand of $105 \mathrm{~kW}$, thermal power of $1528 \mathrm{~kW}$ would be required for absorbent regeneration [26]. Such energy requirements would be detrimental to the performance of a stand-alone hydrogen production plant. However, one can imagine a different situation in the case of an add-on plant integrated with a sugar factory where waste heat for possible use in gas upgrading would be available.

Turning attention to the economic aspects, it should be noted that according to Glenk and Reichelstein [38] the current cost of hydrogen produced at a large scale from fossil sources is around $3 \mathrm{EUR} / \mathrm{kg}$. Moreover, the cost of hydrogen produced in Germany and USA (though not yet at a commercial scale) by water electrolysis using renewable electricity is 3-4 EUR/kg. As the methodology of cost calculation used in [38] is based on statistical analyses of German and US market data, these values are not directly comparable with the cost estimates obtained according to Section 2.2 of the present study. Anyway, as the hydrogen cost calculated here is an order of magnitude higher, the studied concept of hydrogen production from molasses cannot be cost-competitive. In spite of that, information presented in Sections 3.1 and 3.2 deserves further consideration as it allows to identify how process performance and plant characteristics could be changed to substantially improve performance indices. It should also be noted that due to unavoidable energy losses, the energy yield of hydrolysis is less than one, meaning that energy output in hydrogen obtained by water electrolysis is less than the necessary energy input. This implies that the electrolysis route is not easily comparable with hydrogen production from molasses for which energy yield is 1.68; that is, energy output is $68 \%$ greater than the necessary energy input.

Judging from the results of the sensitivity analysis presented in Section 3.2, an increase in hydrogen productivity in photofermentation deserves special attention because in relation to its assumed value of $0.5 \mathrm{mmol} / \mathrm{L} / \mathrm{h}$, the margin of potential improvement is much wider than $20 \%$ assumed in the analysis. Productivity of $0.67 \mathrm{mmol} / \mathrm{L} / \mathrm{h}$ (34\% higher) has been achieved in the investigation of molasses processing [23], while productivity of $1.05 \mathrm{mmol} / \mathrm{L} / \mathrm{h}$ has been reported from the research of hydrogen production from sugar beet thick juice, a feedstock similar to molasses [24]. Moreover, estimates of attainable productivity as high as $3.3 \mathrm{mmol} / \mathrm{L} / \mathrm{h}$ have been mentioned in the literature [39]. If the productivity values of 1.05 or $3 \mathrm{mmol} / \mathrm{L} / \mathrm{h}$ were attained in the two-stage plant for hydrogen production from molasses, then the hydrogen cost reduction could be estimated at around $33 \%$ and $60 \%$, respectively; at the same time, energy yield would be increased by $4 \%$ and $10 \%$, respectively [21]. It is worth noting that similar to productivity increase, photobioreactor design with a reduced footprint (less land area required) also reduces the capital cost of the photofermentation unit thus also contributing to the reduction of hydrogen cost. This reduction effect could probably be achieved by applying photobioreactor modules with stacked tubes as proposed by Kayahan et al. [40].

The sensitivity analysis also indicated that energy yield could be raised by increasing the conversion factor of sucrose in thermophilic fermentation. However, increasing it above the value 0.7 achieved in the experiments may be difficult to attain in industrial applications. While a possible value as high as 0.85 has been mentioned in the literature [25], the conversion factor is limited by unavoidable sucrose losses in fermentation as already explained in Section 2.2. Actually, a more significant potential energy yield improvement can be attributed to the increase of sucrose concentration in the solution supplied to the thermophilic fermentation because its experimentally confirmed value of $10 \mathrm{~g} / \mathrm{L}$ is much below the estimated limit of $40 \mathrm{~g} / \mathrm{L}$ [25]. While there are no indications this limiting value could be approached in the foreseeable future, if a more realistic sucrose concentration of $20 \mathrm{~g} / \mathrm{L}$ (i.e., increased by $100 \%$ ) was attained, then the energy yield would be around 2.1 (25\% improvement [21]).

Looking for opportunities to reduce hydrogen cost, one may consider increasing the output of the production plant. However, some economy of scale may be available only in the dark fermentation and gas upgrading units. Both capital costs and operating costs of the plant depend mainly on the size of 
photofermentation unit understood as the total required length of transparent tubes in the bioreactors. As this size increases linearly with plant output, so does contribution of the photofermentation unit to the total production costs, implying no economy of scale in this unit. It is estimated that a plant output increased by a factor of 10 (energy stream in the produced hydrogen raised from $2 \mathrm{MW}$ to $20 \mathrm{MW}$ ) could reduce hydrogen cost by not more than $5 \%$.

\section{Conclusions}

Suitability of two-step fermentative hydrogen production, using molasses as feedstock, for industrial applications was studied. The study included simulation of the production process and evaluation of the performance of a plant whose hydrogen output is equivalent to an energy stream of $2 \mathrm{MW}$. Hydrogen cost-calculated assuming the economic conditions of Poland-was selected as the main economic index, and energy yield was used as the supplementary technological index. To the knowledge of the present authors, a detailed techno-economic evaluation of two-step molasses-based hydrogen fermentation was carried out for the first time. Assuming conservative values of process parameters, the hydrogen cost was estimated at around $33 \mathrm{EUR} / \mathrm{kg}$ (and the energy yield at 1.68). This clearly indicates that at such process parameters the hydrogen production plant cannot be competitive because the current cost-level of hydrogen produced in Germany and the USA at large scales from fossil sources is below $2.7 \mathrm{EUR} / \mathrm{kg}$. Moreover, using the available schemes of support for renewable energy, the cost of hydrogen produced by water electrolysis using renewable electricity (up to now, at a small scale only) is below $3.2 \mathrm{EUR} / \mathrm{kg}$, and can be expected to go down in the coming decades.

Sensitivity analysis was subsequently performed, also for the first time in the pertinent literature, aiming at both identification of measures to improve plant performance and estimation of their effects. As the most promising improvement measure, increased hydrogen productivity in the photofermentation unit was identified. While a productivity value of $0.50 \mathrm{mmol} / \mathrm{L} / \mathrm{h}$ was assumed in the simulation study, some published results of the experimental research on photofermentation indicate values above $1.00 \mathrm{mmol} / \mathrm{L} / \mathrm{h}$ may be achieved. This would make it possible to reduce hydrogen cost by $33 \%$ and increase energy yield by $4 \%$. If photobioreactor design with a reduced footprint was applied, then cost reduction would be more pronounced.

Plant performance could also be significantly improved by increasing sucrose concentration in the solution supplied to thermophilic fermentation above the value of $10 \mathrm{~g} / \mathrm{L}$ assumed in the simulation study. At $20 \mathrm{~g} / \mathrm{L}$, the energy yield would be raised by $25 \%$. If sucrose conversion in the thermophilic fermentation was also increased, then improvement of the energy yield would be more pronounced, and in addition, hydrogen cost could be slightly reduced.

Relying on the abovementioned figures only, that is, neglecting improvement potential associated with changes of other process and plant parameters, hydrogen cost reduction to around $22 \mathrm{EUR} / \mathrm{kg}$ and energy yield increase to around 2.4 could be attained in not too distant future. At this cost level, hydrogen production from molasses in a stand-alone plant employing thermophilic fermentation followed by photofermentation would also not remain competitive. Utilization of the potential of further improvement, through increasing sucrose concentration at the inlet to thermophilic fermentation to $40 \mathrm{mg} / \mathrm{L}$ and hydrogen productivity in the photofermentation unit to $3 \mathrm{mmol} / \mathrm{L} / \mathrm{h}$, may be possible in the long term but a question arises whether or not the perspective of a cost reduction to not less than $12 \mathrm{EUR} / \mathrm{kg}$ (considering also uncertainty margin of at least $\pm 1.2 \mathrm{EUR} / \mathrm{kg}$ ) is sufficient for justifying the necessary research effort.

Further research on fermentative hydrogen production from molasses, and probably also from other biomass-derived feedstocks, could explore the concept of an add-on plant integrated with the feedstock source. In the case of molasses processing, hydrogen cost would be substantially reduced as the add-on plant could use waste heat discharged from the sugar factory while avoiding investment in certain plant subsystems, such as molasses storage and wastewater treatment. 
Author Contributions: Conceptualization, R.G.; methodology, R.G. and K.U.; investigation, R.G.; data curation, R.G.; writing—original draft preparation, R.G., K.U. and J.W.; writing—review and editing, R.G., K.U. and J.W.; visualization, R.G. and M.T.; supervision, R.G and K.U.; funding acquisition, J.W.

Funding: The APC was funded by the Town of Płock through the Mayor's Research Grants Programme "Collaborations with Universities".

Conflicts of Interest: The authors declare no conflict of interest.

\section{References}

1. Hu, Y.; Peng, L.; Li, X.; Yao, X.; Lin, H.; Chi, T. A novel evolution tree for analyzing the global energy consumption. Energy 2018, 147, 1177-1187. [CrossRef]

2. BP Statistical Review of World Energy. 2019. Available online: www.bp.com (accessed on 4 October 2019).

3. Zecca, A.; Chiari, L. Fossil-fuel constraints on global warming. Energy Policy 2010, 38, 1-3. [CrossRef]

4. Ameyaw, B.; Yao, L.; Oppong, A.; Agyema, J. Investigating, forecasting and proposing emission mitigation pathways for $\mathrm{CO}_{2}$ emission from fossil fuel combustion only: A case study of selected countries. Energy Policy 2019, 130, 7-21. [CrossRef]

5. Li, Y.C.; Liu, Y.F.; Chu, C.Y.; Chang, P.L.; Hsu, C.W.; Lin, P.J.; Wu, S.Y. Techno-economic evaluation of biohydrogen production from wastewater and agricultural waste. Int. J. Hydrogen Energy 2012, 37, 15704-15710. [CrossRef]

6. Rosen, M.A.; Koohi-Fayegh, S. The prospects for hydrogen as an energy carrier: An overview of hydrogen energy and hydrogen energy systems. Energy Ecol. Environ. 2016, 1, 10-29. [CrossRef]

7. Yong, J.Y.; Klemeš, J.J.; Varbanov, P.S.; Huisingh, D. Cleaner energy for cleaner production: Modelling, simulation, optimisation and waste management. J. Clean. Prod. 2016, 111, 1-16. [CrossRef]

8. Azzaro-Pantel, C. Preface Hydrogen Supply Chains: Design, Deployment, and Operation. In Hydrogen Supply Chains; Elsevier: Amsterdam, The Netherlands, 2018.

9. Claassen, P.A.M.; De Vrije, T.; Koukios, E.; Van Niel, E.; Eroglu, I.; Modigell, M.; Friedl, A.; Wukovits, W.; Ahrer, W. Non-thermal production of pure hydrogen from biomass: Hyvolution. J. Clean. Prod. 2010, 18, 4-8. [CrossRef]

10. Keskin, T.; Hallenbeck, P.C. Enhancement of Biohydrogen Production by Two-Stage Systems: Dark and Photofermentation. In Biomass Conversion: The Interface of Biotechnology, Chemistry and Materials Science; Springer: Berlin/Heidelberg, Germany, 2012; pp. 313-340.

11. Panagiotopoulos, J.A.; Bakker, R.R.; De Vrije, T.; Urbaniec, K.; Koukios, E.G.; Claassen, P.A.M. Prospects of utilization of sugar beet carbohydrates for biological hydrogen production in the EU. J. Clean. Prod. 2010, 18, 9-14. [CrossRef]

12. Urbaniec, K.; Grabarczyk, R. Hydrogen production from sugar beet molasses-A techno-economic study. J. Clean. Prod. 2014, 65, 324-329. [CrossRef]

13. Tunçay, E.G.; Erguder, T.H.; Eroğlu, İ.; Gündüz, U. Dark fermentative hydrogen production from sucrose and molasses. Int. J. Energy Res. 2017, 41, 1891-1902. [CrossRef]

14. Gabra, F.A.; Abd-Alla, M.H.; Danial, A.W.; Abdel-Basset, R.; Abdel-Wahab, A.M. Production of biofuel from sugarcane molasses by diazotrophic Bacillus and recycle of spent bacterial biomass as biofertilizer inoculants for oil crops. Biocatal. Agric. Biotechnol. 2019, 19, 101112. [CrossRef]

15. Kayahan, E.; Eroglu, I.; Koku, H. A compact tubular photobioreactor for outdoor hydrogen production from molasses. Int. J. Hydrogen Energy 2017, 42, 2575-2582. [CrossRef]

16. Han, W.; Liu, Z.; Fang, J.; Huang, J.; Zhao, H.; Li, Y. Techno-economic analysis of dark fermentative hydrogen production from molasses in a continuous mixed immobilized sludge reactor. J. Clean. Prod. 2016, 127, 567-572. [CrossRef]

17. EEA. Recent Growth and Knock-on Effects; EEA Report 20/2018: Renewable Energy in Europe-2018; European Environment Agency: Luxembourg, 2018; ISBN 978-92-9480-044-2.

18. Portal Gospodarczy. Available online: www.wnp.pl (accessed on 10 July 2019).

19. International Sugar Organization. Available online: www.isosugar.org/sugarsector/by-products (accessed on 30 March 2019).

20. Suedzucker. Available online: www.suedzucker.pl (accessed on 15 April 2019). 
21. Grabarczyk, R. Techno-Economic Analysis of the Process Plant to Produce Hydrogen by Two-Step Fermentation. Ph.D. Thesis, Warsaw University of Technology, Warsaw, Poland, 2019. (In Polish).

22. Narodowy Fundusz Ochrony Środowiska i Gospodarki Wodnej. Available online: www.mfosigw.gov.pl (accessed on 8 April 2019).

23. Avcioglu, S.G.; Ozgur, E.; Eroglu, I.; Yucel, M.; Gunduz, U. Biohydrogen production in an outdoor panel photobioreactor on dark fermentation effluent of molasses. Int. J. Hydrogen Energy 2011, 36, 11360-11368. [CrossRef]

24. Uyar, B.; Gürgan, M.; Özgür, E.; Gündüz, U.; Yücel, M.; Eroglu, I. Hydrogen production by hup-mutant and wild-type strains of Rhodobacter capsulatus from dark fermentation effluent of sugar beet thick juice in batch and continuous photobioreactors. Bioprocess. Biosyst. Eng. 2015, 38, 1935-1942. [CrossRef] [PubMed]

25. Ljunggren, M.; Zacchi, G. Techno-economic evaluation of a two-step biological process for hydrogen production. Biotechnol. Prog. 2010, 26, 496-504. [CrossRef] [PubMed]

26. Markowski, M.; Urbaniec, K.; Budek, A.; Wukovits, W.; Friedl, A.; Ljunggren, M.; Zacchi, G. Heat Integration of a Fermentation-Based Hydrogen Plant Connected with Sugar Factory. In Proceedings of the Chemical Engineering Transactions; Italian Association of Chemical Engineering-AIDIC: Rome, Italy, 2009; Volume 18, pp. 351-356.

27. Kumar, G.; Shobana, S.; Nagarajan, D.; Lee, D.J.; Lee, K.S.; Lin, C.Y.; Chen, C.Y.; Chang, J.S. Biomass based hydrogen production by dark fermentation-Recent trends and opportunities for greener processes. Curr. Opin. Biotechnol. 2018, 50, 136-145. [CrossRef]

28. Markowski, M.; Urbaniec, K.; Budek, A.; Trafczyski, M.; Wukovits, W.; Friedl, A.; Ljunggren, M.; Zacchi, G. Estimation of energy demand of fermentation-based hydrogen production. J. Clean. Prod. 2010, 18, 81-87. [CrossRef]

29. Modigell, M.; Schumacher, M.; Beggel, F.; Guichard, J.; Sequeira, S.E.; Teplyakov, V.V.; Zenkevitch, V.B. Evaluation of different gas upgrading technologies in biohydrogen production processes. In Proceedings of the CHISA 2008 - 18th International Congress of Chemical and Process Engineering, Prague, Czech Republic, 24-28 August 2008.

30. Özgür, E.; Mars, A.E.; Peksel, B.; Louwerse, A.; Yücel, M.; Gündüz, U.; Claassen, P.A.M.; Eroglu, I. Biohydrogen production from beet molasses by sequential dark and photofermentation. Int. J. Hydrogen Energy 2010, 35, 511-517. [CrossRef]

31. Brown, T. Engineering Economics. In Engineering Economics and Economic Design for Process Engineers; CRC Press: Boca Raton, FL, USA, 2006; ISBN 9780849382123.

32. Turton, R.; Bailie, R.C.; Whiting, W.B.; Shaeiwitz, J.A. Analysis, Synthesis and Design of Chemical Processes, 3rd ed.; Prentice Hall: New York, NY, USA; London, UK, 2009; ISBN 9780135129661.

33. Smith, R. Chemical Process Design and Integration, 2nd ed.; John Wiley \& Sons: Chichester, UK, 2016; ISBN 1118699084.

34. DOE. Engineering Economic Analysis Guide: Liquid Fuels Technologies; U.S. Department of Energy: Washington, DC, USA, 2015.

35. Pfeifer \& Langen Poland. Available online: www.diamant.pl (accessed on 6 February 2019).

36. Energa. Available online: www.energa.pl (accessed on 6 February 2019).

37. Główny Urząd Statysytczny. Available online: Stat.gov.pl (accessed on 6 February 2019).

38. Glenk, G.; Reichelstein, S. Economics of converting renewable power to hydrogen. Nat. Energy 2019, 4, 216-222. [CrossRef]

39. Claassen, P. Non-thermal production of pure hydrogen from biomass-EU FP6-SES Integrated Project Hyvolution. In Proceedings of the World Hydrogen Energy Conference, Essen, Germany, 16-21 May 2010.

40. Kayahan, E.; Eroglu, I.; Koku, H. Design of an outdoor stacked-Tubular reactor for biological hydrogen production. Int. J. Hydrogen Energy 2016, 41, 19357-19366. [CrossRef]

(C) 2019 by the authors. Licensee MDPI, Basel, Switzerland. This article is an open access article distributed under the terms and conditions of the Creative Commons Attribution (CC BY) license (http://creativecommons.org/licenses/by/4.0/). 